\title{
Total occlusion of the left main coronary artery presenting with atypical symptoms
}

\author{
Atipik semptomlarla seyreden sol ana koroner arter total tıkanıklığı
}

Şeref Alpsoy, Aydın Akyüz, Dursun Cayan Akkoyun, Hasan Değirmenci

Namık Kemal Üniversitesi, Tıp Fakültesi, Kardiyoloji AD., Tekirdağ

\begin{abstract}
Left main coronary artery total occlusion is rarely determined by coronary angiography because; it almost always results in death. Here, we report a case of a 55 year old man who was admitted to our clinic with exertional angina and palpitations. He also had a history of dizziness, sweating and faintness six months previously due to total occlusion of the left main coronary artery.
\end{abstract}

Pam Med J 2014;7(1):75-78

Key words: Coronary arteries, coronary occlusion, myocardial infarction.

\section{Özet}

Sol ana koroner arter tıkanıklıkları genellikle ölümle sonuçlandığı için koroner anjiyografilerde nadir saptanır. Kliniğimize efor anjinası ve çarpıntı ile başvuran ve 6 ay önce sol ana koroneri tam tıkanıklığına bağlı terleme, baş dönmesi ve bayılma hissi hikayesi olan 55 yaşında erkek bir olguyu sunduk.

Pam Tip Derg 2014;7(1):75-78

Anahtar sözcükler: Koroner arterler, koroner tıkanma, miyokart enfarktüsü.

\section{Introduction}

Left main coronary artery (LMCA) stenosis of $50 \%$, defined as an obstructive disease, is a poor predictor for long term prognosis [1]. Although the chance of survival depends on the time between symptom onset and hospital arrival, acute total occlusion of LMCA is almost always fatal.

Chronic total occlusion of LMCA is presented with angina, myocardial infarction and congestive heart failure [2]. We aimed to present a patient with atypical symptoms related to myocardial infarction due to total occlusion of the LMCA.

\section{Case report}

Fifty-five year-old male patient was admitted to the cardiology clinic due to exercise-induced angina and palpitations which started two weeks ago. He had the following risk factors for coronary artery disease (CAD); family history of CAD, smoking, hypertension, and hyperlipidemia. He was not taking cardiovascular drugs and had no diabetes mellitus. He had not suffered from any serious illness until admission to our hospital. With a detailed history, he had a history of sweating episodes, dizziness and near-syncope of 15-20 minutes at rest about 6 months previously. The patient had experienced several episodes with the same duration in a month. Previous myocardial infarction was diagnosed in our clinic, after a general practitioner's proposal. On physical examination, his arterial blood pressure was $110 / 70 \mathrm{~mm} \mathrm{Hg}$, pulse rate was 110 beats / $\mathrm{min}$ and irregular. Left ventricle S3 was present and lung areas were clean as well as his NHYA functional capacity was 2 . There

Şeref Alpsoy

Yazışma Adresi: Namık Kemal Üniversitesi, Tıp Fakültesi, Kardiyoloji AD., Tekirdağ

e-mail: srfalpsoy@hotmail.com

Gönderilme tarihi: 18.05.2013

Kabul tarihi: 24.09.2013 
was no extremity edema. Electrocardiography showed atrial fibrillation with a form of QS in leads $V$ 1-6. Echocardiographic examination revealed that the left ventricular diameters increased (left ventricle diastolic diameter 65 $\mathrm{mm}$, systolic diameter $55 \mathrm{~mm}$ ), the septum, anterior and apex were akinetic and the lateral wall was hypokinetic; ejection fraction was $27 \%$ detected by the Simpson's method, the patient underwent coronary angiography. Total occlusion of the LMCA was detected along with the normal right coronary artery (RCA), which was well-developed and dominant. RCA had formed a rentrop III collateral circulation to the left coronary artery system (Fig 1, 2, 3).

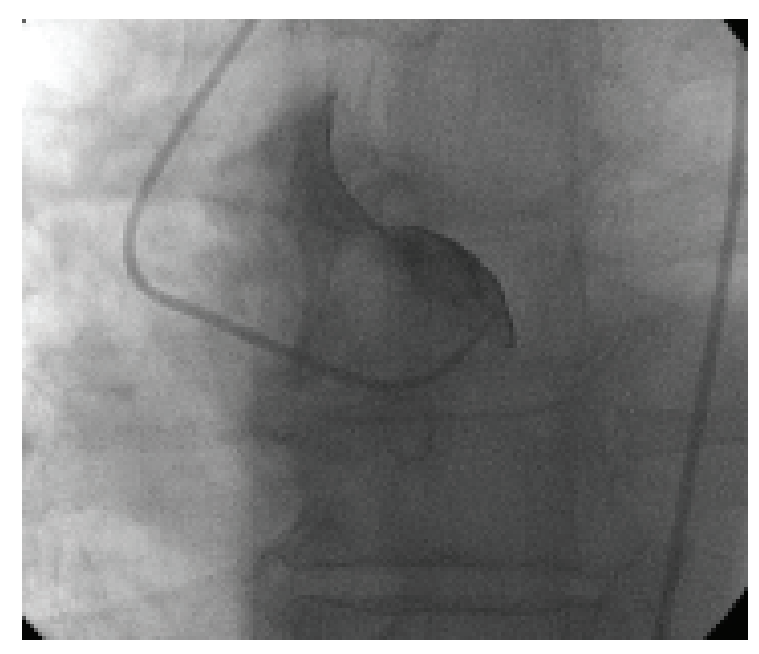

Figure 1. Left main coronary artery ostium was not seen in left sinus valsalva.

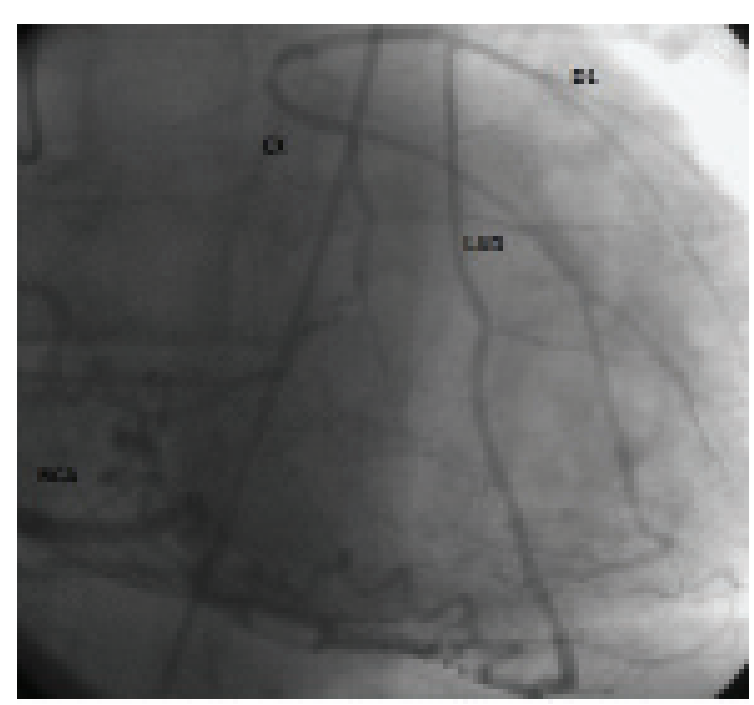

Figure 2. A well-developed collateral network from right to left coronary artery system is seen.

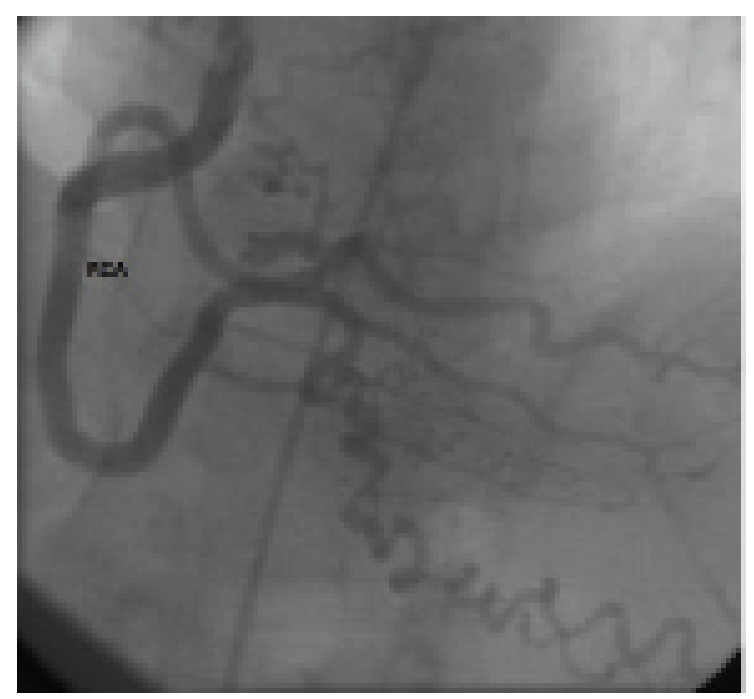

Figure 3. There is no stenotic lesion in the right coronary artery.

In order to exclude coronary anomaly such as Anomalous origin of the left coronary artery from the pulmonary artery (ALCAPA) syndrome, a multislice computed tomography was recommended, but the patient did not accept it. Hence, echocardiography was repeated to reveal whether there was coronary artery origin anomaly or not. There was no vascular structure originating from the pulmonary artery. Another echocardiographic finding of ALCAPA syndrome is that also the right coronary artery / aortic root ratio is higher than 0.14 . Right coronary artery to aortic root ratio was calculated to be 0.12 in our case (Figure 4).

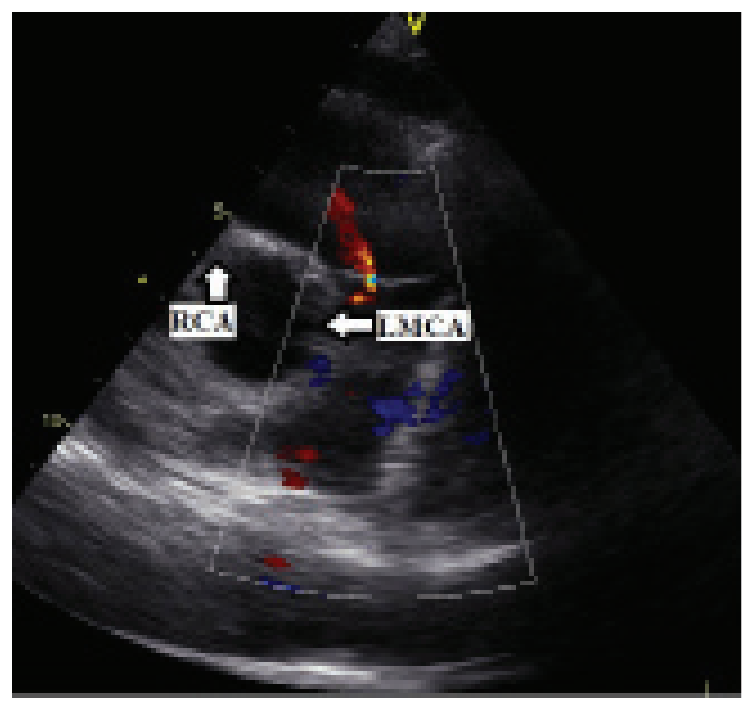

Figure 4. Echocardiographic parasternal short axis wiev showed that LMCA and RCA originated from left and right sinus of Valsalva. 
In addition, fast reverse flow into the pulmonary artery through the collateral arteries could be displayed on the interventricular septum. We also showed that there was no fast reverse flow on the interventricular septum. Thallium scintigraphy showed a large anterior, septal, apical scar and minimal midlateral wall ischemia. Coronary artery by-pass graft operation was not performed due to his scintigraphic result reporting too much scar tissue and minimal ischemia. Implantable cardioverter defibrillator implantation could not be placed due to the patients' refusal. The patient was discharged with angiotensin converting enzyme inhibitor, beta blocker, aspirin, statin, aldosterone antagonist and warfarin therapy. When patient came for his 3 monthly check-up , his clinical situation was stable. ECG showed a sinus rhythm (Figure 5).

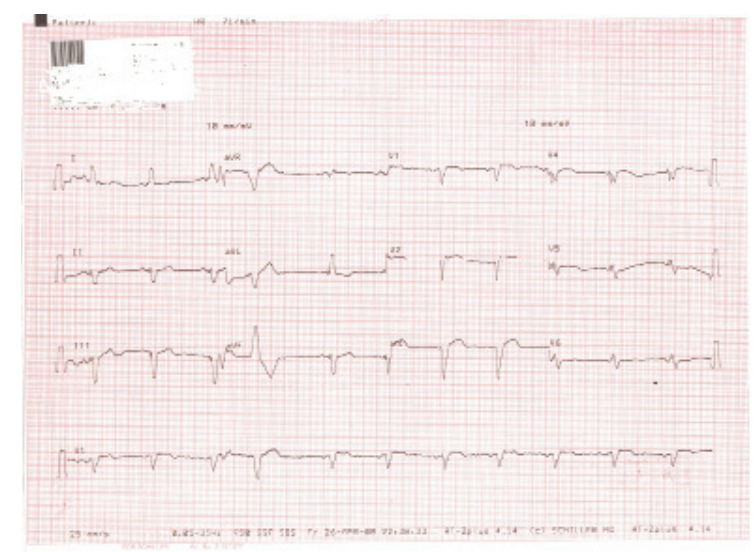

Figure 5. Electrocardiogram showed that sinus rhytm and QS formation in lead V1-5.

\section{Discussion}

Total occlusion of LMCA is rare in patients undergoing coronary angiography, because it usually results in sudden death [3]. The incidence of it ranges from 0.04 to $0.43 \%$ [4]. If a patient has a well-developed collateral network from right to left coronary system and a right dominant coronary anatomy, his/her survival may be possible. Well developed collateral vessels do not change exertional angina, even though there are protective features for ischemia and ventricular function [5]. Total LMCA occlusion can be acute or chronic. Acute LMCA occlusion usually associates with sudden death, cardiogenic shock as well as ST elevation myocardial infarction. Chronic LMCA total occlusion might be seen with silent ischemia, exercise-induced angina, unstable angina pectoris and heart failure [4]. Atherosclerotic total occlusion, the most common cause of LMCA occlusion, is more common in elderly patients with diabetes mellitus and in male smokers [6, 7].

In our case presented here with exertional angina. Decreased pain threshold of the patient who was asymptomatic for about 6 months is suggests that progressive left ventricle systolic dysfunction may be associated with a lower pain threshold in time due to the metabolic effects of heart failure. The point we wish to emphasize here, is according to our classical knowledge emergency $\mathrm{CABG}$ is required for LMCA stenosis of $50 \%$ or more, but our patient survived from sudden death due to very welldeveloped collaterals from a right dominant coronary artery. As can be seen in coronary angiography, both the LAD and CX are very well visualized, retrogradely. We assumed that the patient probably had chronic progressive and severe stenosis of the LMCA, and developed a rich collateral circulation right to left, and then a total occlusion occured. Unlike this assumption, survival is not possible. In a study, patients who presented with acute anterolateral myocardial infarction and left main coronary artery stenosis of more than $75 \%$, regardless of the type of intervention, death rate was found to be $94 \%$ and $5 \%$ in patients with and without cardiogenic shock respectively [8].

In conclusion, acute LMCA total occlusion often leads to serious clinical manifestations. However, acute myocardial infarction may rarely present with atypical symptoms. Ischemia and myocardial infarction should always be kept in mind in patients who have atypical symptoms such as near syncope, fainting and sweating.

Conflict of Interest: The authors report no conflict of interest.

\section{References}

1. Ricciardi M.J, Meyers S, Choi K, Pang J.L, Goodreau L, Davidson C.J. Angiographically silent left main disease detected by intravascular ultrasound: a marker for future adverse cardiac events. Am Heart J 2003; 146:507-512.

2. Kanjwal MY, Carlson Jr, Schwartz JS. Chronic/sub acute total occlusion of the left main coronary artery--a case report and review of literature. Angiology. 1999 ; 50:937-945. 
3. Shirasawa K, Hwanga MW, Sasaki Y. et al. Chronic total occlusion of the left main coronary artery with normal left ventricular motion: the occluded site confirmed by three-dimensional computed tomography. Int J Cardiol 2010;139:193-209.

4. Shahian DM, Butterly JR, Malacoff RF. Total obstruction of the left main coronary artery. Ann Thorac Surg 1988; 46:317-320.

5. Slunga L, Eriksson P, Osterman G. Complete occlusion of the left main coronary artery: clinical and angiographic observations in five cases. J Intern Med 1989;225:123-120.
6. On Topaz, M.D Total left main coronary artery occlusion. The acute, the chronic, and the iatrogenic. Chest 1992; 101:843-846.

7. Shaıkh MY, Ahmad M, Rasheed A, Jan DM, Alı M. Left main disease - patıent profile. Pakistan Heart J 2007; 40:19-23.

8. Quigley RL, Milano CA, Smith LR, White WD, Rankin JS, Glower DD. Prognosis and management of anterolateral myocardial infarction in patients with severe left main disease and cardiogenic shock. The left main shock syndrome. Circulation 1993;88:1165-1170. 